University of Nebraska - Lincoln

DigitalCommons@University of Nebraska - Lincoln

New Host and Elevation Records for Moneilema appressum Leconte (Coleoptera: Cerambycidae: Lamiinae)

Steven Lingafelter

Systematic Entomology Laboratory, PSI, ARS, USDA and National Museum of Natural History, MRC-168, Smithsonian Institution, Washington, D.C. 20560, U.S.A.

Follow this and additional works at: https://digitalcommons.unl.edu/systentomologyusda

Part of the Entomology Commons

Lingafelter, Steven, "New Host and Elevation Records for Moneilema appressum Leconte (Coleoptera: Cerambycidae: Lamiinae)" (2003). USDA Systematic Entomology Laboratory. 29.

https://digitalcommons.unl.edu/systentomologyusda/29

This Article is brought to you for free and open access by the Entomology Collections, Miscellaneous at DigitalCommons@University of Nebraska - Lincoln. It has been accepted for inclusion in USDA Systematic Entomology Laboratory by an authorized administrator of DigitalCommons@University of Nebraska - Lincoln. 


\title{
NEW HOST AND ELEVATION RECORDS FOR MONEILEMA APPRESSUM LECONTE (COLEOPTERA: CERAMBYCIDAE: LAMIINAE)
}

\author{
Steven W. Lingafelter \\ Systematic Entomology Laboratory, PSI, ARS, USDA and National Museum of Natural \\ History, MRC-168, Smithsonian Institution, Washington, D.C. 20560, U.S.A.
}

Abstract.-An isolated population of Moneilema appressum LeConte was discovered above Long Park in the Chiricahua Mountains of southeastern Arizona $\left(31^{\circ} 52^{\prime} 44^{\prime \prime} \mathrm{N}, 109^{\circ} 17^{\prime} 12^{\prime \prime} \mathrm{W}\right)$ during July 2001. Specimens of this flightless lamiine cerambycid were observed hiding and walking in the junctures of Echinocereus coccineus Engelmann (Cactaceae) at 2,760 m (9,055 feet). These data represent new host plant and elevation records for this species.

Key words: Moneilema, Echinocereus, Opuntia, cactus, Lamiinae, Arizona, hostplants, elevation record.

In July 2001, a Coleoptera collecting and research expedition was undertaken to southeastern Arizona around the Southwestern Research Station. An isolated population of Moneilema appressum LeConte was discovered on a genus of cacti never before recorded and at a record elevation.

Moneilema appressum was described in 1852 by John LeConte from a single specimen from New Mexico. Over the next 150 years, 11 species have been proposed for what are actually minor population variants. Most of these were synonymized in Linsley and Chemsak (1984).

This species occurs from northern Mexico to western Texas, west to Arizona and north to Colorado (Linsley and Chemsak, 1984). The only host genus for Moneilema appressum listed by Linsley and Chemsak (1984) and Linsley and Chemsak (1997) is Opuntia. In contrast, in his revision of the genus of Mexico and North America, Psota (1930) indicated that most species of Moneilema were collected on Echinocereus. However, the cacti he was referring to (and as illustrated in Plates A-D of that paper) are actually cholla cacti of the genus Opuntia. In his unpublished dissertation on Moneilema, Raske (1966) observed Moneilema appressum on Echinocereus (presumably correctly identified since he pointed out Psota's cactus identification error), but he provided no specific details as to locality or numbers of individuals. There are no published records of Moneilema appressum occurring on anything other than Opuntia.

The cactus Echinocereus coccineus was described by Engelmann in Wislizenus (1848). Current authors disagree on the valid name of this species. Taylor (1985) referred to it under the name, E. triglochidiatus var. melanacanthus. He stated that the name Cereus coccineus is an illegitimate homonym, and its epithet cannot be employed according to Article 57.1 of the Botanical Code. Blum et al. (1998) apparently disagree and used the name Echinocereus coccineus Engelmann.

\section{OBSERVATIONS AND DISCUSSION}

Alexander Konstantinov discovered a specimen of Moneilema appressum LeConte on an isolated patch of cacti on a steep, rocky slope (Fig. 1) at 2,760 m (9,055 feet), above the Long 


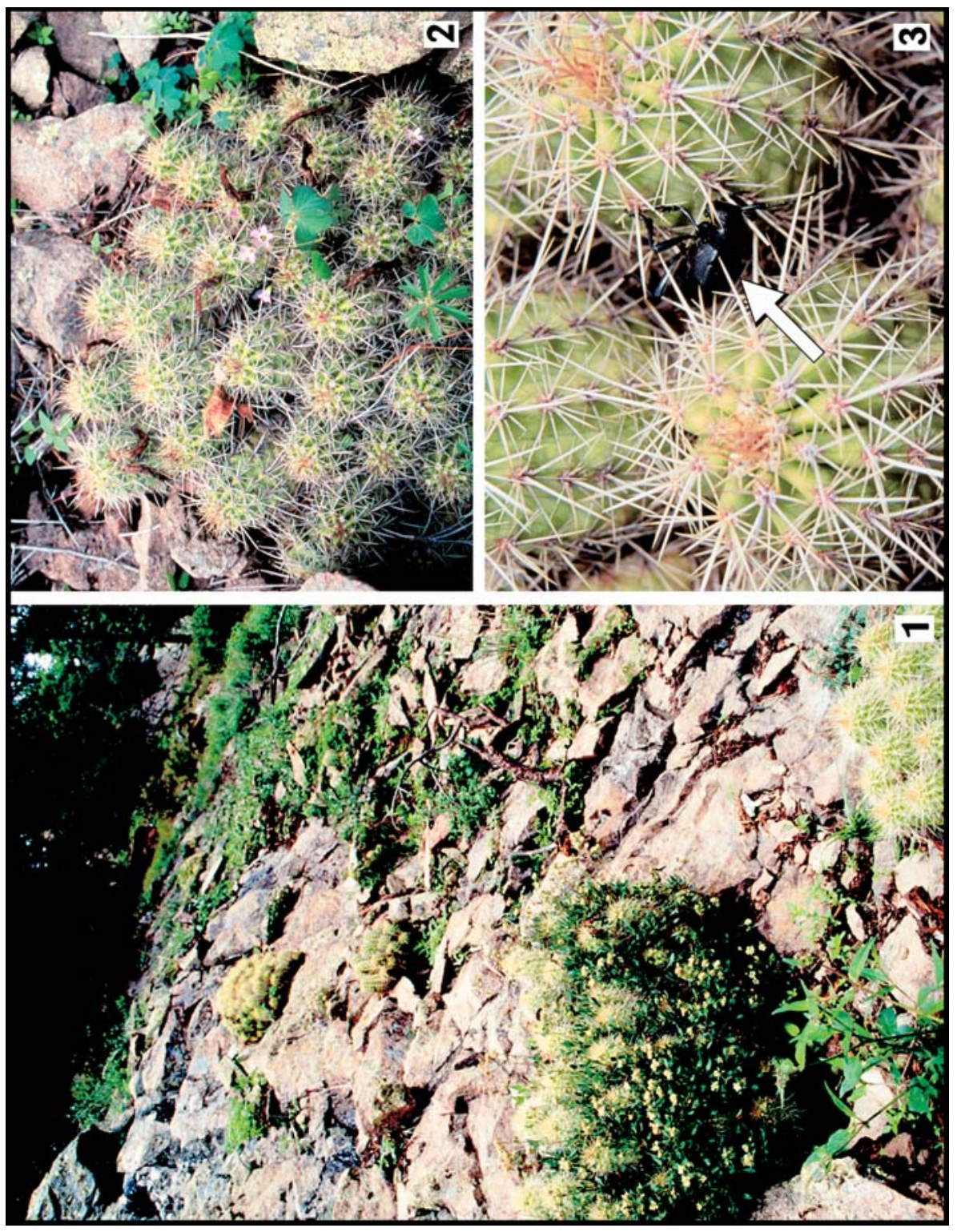


Park area (above Rustler Park) of the Chiricahua Mountains $\left(31^{\circ} 52^{\prime} 44^{\prime \prime} \mathrm{N}, 109^{\circ} 17^{\prime} 12^{\prime \prime} \mathrm{W}\right)$, Cochise Co., Arizona. The host cacti, Echinocereus coccineus Engelmann, are small $(<12 \mathrm{~cm}$ tall) and were growing in tight, spiny clumps (Fig. 2) in a ca. $30 \mathrm{~m}$ wide band along the slope. Above and below this band, conifers were prevalent and no other cacti were seen in the vicinity. The flightless condition of Moneilema appressum, the strict association of Moneilema to cacti, the absence of any other species of cacti from the vicinity, and the extreme elevational isolation of this population (the closest population encountered was near the southwestern research station, nearly 3,000 feet below), together are evidence that establish Echinocereus coccineus as a valid host for Moneilema appressum.

Alexey Tishechkin and I made two subsequent, focussed collections to the site and obtained 20 specimens, most having to be extricated from the tight junctures of the cacti (Fig. 3). Not all specimens seen were collected, and many additional cacti could not be examined because they were on a slope too precarious and steep to be accessed. The specimens are deposited at the National Museum of Natural History, Smithsonian Institution (USNM) and Louisiana State University collections.

The cactus, Echinocereus coccineus, represents a new host genus for Moneilema appressum. This discovery also represents a significant elevational record since no published records exist for this species above 8,000 ft. Only a few other species of Moneilema occur as high as 8,000-10,000 ft. Most of these records are listed in Raske (1966). They include: Moneilema semipunctatum LeConte from the White Mountains, California $\left(9,500^{\prime}\right), M$. ebeninum Bates from Atlacomulco, Mexico $\left(8,000^{\prime}\right), M$. blapsides (Newman) from Durango, Mexico $\left(8,000-9,000^{\prime}\right)$, and M. variolare Thomson from Hidalgo, Mexico $\left(8,000^{\prime}\right)$.

Because Moneilema appressum (like all species in the genus) is flightless, the discovery of such an isolated population is intriguing. Because of the poor ability of these beetles to disperse, their presence at such an isolated place suggests that they may represent a fragment of a formerly widespread population that became isolated because something caused the predominant host, Opuntia, to disappear rapidly from higher elevations (thus leaving a relictual population to shift to the only other available cactus or die). This event was probably rapid because if it were gradual, the Moneilema and Opuntia populations would most likely maintain a natural balance (as they do at lower elevations) and no major host shifts of the kind observed would be driven because the selection pressure would be inadequate. This scenario is corroborated by the fact that opportunistic host shifts on Echinocereus have not been seen in any other localized situations even though these cacti occur together frequently and with variable population densities at lower elevations. However, another possibility may be that the Moneilema population represents a recent colonization event spurred by increased population pressures combined with localized extirpation of Opuntia, triggering a host shift (C. I. Smith, pers. comm.). The recency of this latter event may be more likely as climatic studies suggest that up until 10,000 years bp, the temperature conditions at this elevation were too cold for any of these species to survive (based on paleoclimatic studies of Van Devender, 1990; Brown

Fig. 1. Steep slope containing narrow band of Echinocereus coccineus Engelmann cacti and Moneilema appressum LeConte beetles at 2,760 m (9,055 feet), above the Long Park area (above Rustler Park) of the Chiricahua Mountains ( $\left.31^{\circ} 52^{\prime} 44^{\prime \prime} \mathrm{N}, 109^{\circ} 17^{\prime} 12^{\prime \prime} \mathrm{W}\right)$, Cochise Co., Arizona. Fig. 2. Cluster of Echinocereus coccineus Englemann growing amid rocky outcrop. Fig. 3. Close-up of Echinocereus coccineus Engelmann cactus with an adult Moneilema appressum LeConte protected by the tight, spiny junctures. 
and Lomolino, 1998). It is hoped that ongoing studies of C. I. Smith and others will elucidate the relevant factors contributing to host shifts in Moneilema, but until more study is done, this population will remain an enigma.

\section{ACKNOWLEDGMENTS}

This note would have been impossible without the discovery of this population made by Alexander Konstantinov (SEL-USDA). I thank him and Alexey Tishechkin (Louisiana State University) for collecting specimens. Norman Woodley (SEL-USDA), Ainsley Seago (Cornell University), Alexander Konstantinov, and Alexey Tishechkin provided great companionship during our Arizona expedition. Wade Sherbrooke and others at the Southwestern Research Station provided generous logistical support during my stay there. Frank Hovore provided some unpublished information regarding Moneilema distribution. Christopher Irwin Smith (Harvard University) provided insightful comments and suggestions. Further reviews were provided by John Brown, Allen Norrbom (both SEL-USDA) and Charlie Staines (USNM).

\section{LITERATURE CITED}

Blum, W., M. Lange, W. Rischer and J. Rutow. 1998. Echinocereus. Aachen, Belgium. 496 pp.

Brown, J. H. and M. V. Lomolino. 1998. Biogeography, 2nd edition. Sinauer Associates, Sunderland, Massachusetts. $560 \mathrm{pp}$.

LeConte, J. L. 1852. An attempt to classify the longicorn Coleoptera of the part of America north of Mexico. Journal of the Academy of Natural Sciences at Philadelphia 2(2): 139-178.

Linsley, E. G. and J. A. Chemsak. 1984. The Cerambycidae of North America. Part VII, No. 1: Taxonomy and Classification of the Subfamily Lamiinae, Tribes Parmenini through Acanthoderini. University of California Publications in Entomology 102: 258 pp.

Linsley, E. G. and J. A. Chemsak. 1997. The Cerambycidae of North America. Part VIII: Bibliography, Index, and Host Plant Index. University of California Publications in Entomology 117: $534 \mathrm{pp}$.

Psota, F. J. 1930. The Moneilema of North America and Mexico, I. Coleopterological Contributions 1(2): $111-141$.

Raske, A. G. 1966. Taxonomy and bionomics of the genus Moneilema. Unpublished Ph.D. dissertation, University of California, Berkeley. 268 pp.

Taylor, N. P. 1985. The genus Echinocereus. Timber Press, Portland, Oregon. 160 pp.

Van Devender, T. R. 1990. Late Quaternary vegetation and climate of the Sonoran Desert, United States and Mexico, pp. 134-163, in J. L. Betancourt, T. R. Van Devender and P. S. Martin (eds.), Packrat Middens: The Last 40,000 Years of Biotic Change. University of Arizona Press, Tucson. 472 pp.

Wislizenus, F. A. 1848. Memoir of a tour to northern Mexico connected with Col. Doniphan's Expedition, in 1846 and 1847. 30th Congress, Misc. No. 26.

Received 1 October 2002; accepted 21 March 2003. 